\title{
PROPOSING AN EFFICIENT INDICATOR OF GRAZER DISTRIBUTION ON HETEROGENEOUS HILL VEGETATION
}

\author{
B. WILLIAMS ${ }^{1,2^{*}}-$ S. WALLS ${ }^{3}-$ M. WALSH ${ }^{1}-$ M. GORMALLY ${ }^{2}-$ A. BLEASDALE ${ }^{4}$ \\ ${ }^{1}$ Teagasc Research Centre, Mellows Campus, Athenry, Co. Galway, Ireland \\ (phone: +353-91-845-846; fax: +353-91-845-847) \\ ${ }^{2}$ Applied Ecology Unit, Centre for Environmental Science, National University of Ireland, \\ Galway, University Road, Galway, Ireland \\ (phone: +353-91-492294; fax: +353-91-494598) \\ ${ }^{3}$ Anatrack Ltd, 52 Furzebrook Road, Wareham, Dorset, BH20 5AX, UK \\ ${ }^{4}$ National Parks and Wildlife Service 3rd Floor, Plaza Offices, Headford Road, Galway, Ireland \\ *Corresponding author \\ e-mail: bryony.williams@gmail.com
}

(Received $3^{\text {rd }}$ August 2009 ; accepted $14^{\text {th }}$ December 2009)

\begin{abstract}
Irish and UK uplands and peatlands are of international importance but are under threat from several factors, including heavy grazing pressure. Sheep preferentially graze patches of acid grassland with short dense swards, sometimes referred to as 'grazing lawns', and have been implicated in damage to uplands. The aim of this study was to increase our understanding of resource selection by grazers to further inform the design and implementation of conservation strategies. Grazing lawn frequency and habitat condition were mapped and GPS collars were used to track Scottish Blackface sheep on a hill farm in Ireland. Weighted compositional analysis (multivariate analysis of variance) was used to test for random use of different categories of grazing lawn frequency and habitat condition. Grazing lawn frequency was spatially uneven and habitat condition ranged from undamaged to very severely damaged areas. Typically, selection of differing categories of habitat condition was not significant $(\mathrm{P}>0.05)$, although the highest selection rank was consistently for the 'moderate-undamaged' category. Sheep most selected 1 ha grid squares containing numerous/extensive grazing lawns $(\mathrm{P}<0.05)$ day, night and yearround. As a simple, efficient indicator of hill use by sheep, which would be a valuable input in models predicting grazing impact on hill vegetation, the mapping of grazing lawn frequency is suggested.
\end{abstract}

Keywords: agriculture; ecology; environment; resource management; resource selection

\section{Introduction}

Irish and UK uplands and peatlands are of international importance due to the limited global distribution of the habitats, plant communities and fauna they support [9, 56]. Many of these habitats and associated species are protected under the EC Habitats (92/43/EEC) and Birds (79/409/EEC) Directives [21], and are included in biodiversity action plans [16, 37] and agri-environment scheme measures [14, 49]. Despite this, the quality of remaining upland and peatland continues to be under threat from heavy grazing pressure, burning, afforestation, peat extraction, undergrazing and/or land abandonment [22, 48, 56, 57].

Damage in this study refers to habitat conditions which fail to meet biological conservation objectives. While habitats are affected by natural phenomena such as topography [24] and wind-driven rain [11], management practices including grazing [55] play a key role in habitat condition and can be altered. Therefore, the focus of this study is on grazer behaviour as grazing is the predominant management practice on 
Irish hills where heavy grazing pressure is a main threat [50]. This is also the case in other countries, particularly the UK $[22,48]$.

Damage assessment classifications have been devised for upland areas and include indicators of grazing-related damage $[18,44]$. It is widely known that different grazing animals have different effects on vegetation and that different plant communities and associated soils have different carrying capacities [6, 29, 52]. Numerous researchers have studied the impacts of livestock grazing on upland systems (e.g. [8, 15, 23]) but it is believed that grazer selection of areas with differing condition status has yet to be quantified. It is known that sheep choose to use a small proportion of the total area available to them [61] and exhibit habitat and vegetation selection with a preference for acid grassland patches $[12,35,61]$. Acid grassland can have short, dense swards and often has abundant Nardus stricta (L.), [25] (characteristic plant species described). [45] referred to these conspicuous grassland patches as 'grazing lawns', probably because they are a product of grazing and resemble well maintained lawns.

Plant biomass and herbage intake rates are important factors in foraging efficiency and patch selection by grazers [12]. Damaged areas support a higher percentage cover of exposed soil and, consequently, a lower percentage cover of vegetation [18]. Conversely, grazing lawns have a dense canopy which promotes greater forage yields per bite compared with lightly grazed vegetation [45].

Surprisingly, very little published quantitative information is available on resource selection by sheep grazing heterogeneous hill vegetation [2]. Since then, valuable information on patch selection by sheep has been obtained using plot-based trials with artificial patches and field observations (e.g. [19, 28]), which complements previous trials by [12] for example. GPS tracking devices have recently been used to investigate habitat selection rankings in a complex hill farm environment by collecting a large amount of data round-the-clock with high location accuracy [61]. As management prescriptions on complex hill habitat assemblages probably need to vary between sites [35], GPS tracking, although useful for detailed studies on a number of sites, is unlikely to be carried out on a farm-to-farm basis. Therefore an alternative, more rapid method (that could be carried out at farm level) for estimating grazer distribution, to identify areas under greatest grazing pressure, would be a useful tool in conservation management. [61] investigated habitat selection rankings but acid grassland was considered to be under-represented and no account was taken of habitat condition. Therefore the objectives of this study are to investigate spatio-temporal use of grazing lawns (frequency classified for 1 ha grid squares) and patches with differing habitat condition status.

\section{Methods}

\section{Study area}

The study area comprised of 216.9 ha of upland and peatland at the Teagasc Hill Sheep Farm in Co. Mayo in the west of Ireland (53 $\left.37^{\prime} \mathrm{N}, 09^{\circ} 41^{\prime} \mathrm{W}\right)$. The dominant habitats were blanket bog and wet heath, with fragmented patches of acid grassland. Habitat distribution and sheep selection rankings of habitats are described in full by [61]. The study area, which was within the catchment area of the Erriff River, was part of the Mweelrea/Sheeffry/Erriff Complex candidate Special Area for Conservation and proposed Natural Heritage Area. The study area was on the south-southeasterly slopes of Ben Gorm and ranged in altitude from 15-275 m OD, with the highest, steepest 
slopes in the northwest corner. The site was Class 5 for agricultural land use [26]. Soils were mainly organic, consisting of peats, lithosols, humic/peaty podzols and gleys. Peat depths ranged between 30 and $525 \mathrm{~cm}$ [58]. Pegs marked a 100×100 m grid.

A maritime temperate climate prevailed with the nearest synoptic meteorological station located in Belmullet, Co. Mayo, approximately $70 \mathrm{~km}$ distant. Based on the most recent 30-year averages (1961-1990) recorded at Belmullet, the mean daily temperature was $14.0^{\circ} \mathrm{C}$ in July and $5.7^{\circ} \mathrm{C}$ in January, and the annual mean daily duration of bright sunshine was $3.5 \mathrm{~h}$ [46] undated. The mean annual rainfall 1993-2005 recorded on-site was $2086.4 \mathrm{~mm}$ (L. O'Malley pers. comm.). The minimum and maximum hours of daylight at the study area were calculated as $7 \mathrm{~h} 27 \mathrm{~min}$ and $17 \mathrm{~h} 4 \mathrm{~min}$, respectively.

Scottish Blackface sheep grazed the study area at stocking rates of 0.4 ewes/ha in spring (March-May), 0.9 ewes/ha in summer (June-August) and autumn (SeptemberNovember) and 0.8 ewes/ha in winter (December-February). These calculations were based on 2004-2005 averages, omitted lambs and included hoggets at a ratio of 3 hoggets: 2 ewes. The land was grazed for 348 days in 2004 and 351 days in 2005 and supplementary feed was not given in the study area. Ewes lambed in early April with a productivity of 1.0 lamb/ewe (based on mean data 2004-2006). Approximately 80 females were retained annually as replacements. (L. O’Malley pers. comm.).

\section{Tracking ewes}

Four Scottish Blackface ewes ('core ewes') plus seven substitutes, all two years old, were selected at random at the start of the study. This age group was selected because it had experience of the study area and was likely to survive for the duration of the study. Substitute ewes were tracked only when core ewes were unavailable pre-lambing either because they were of low body condition or twin-bearing. Four ewes were tracked in each of nine season-based tracking periods between February 2004 and April 2006 producing 36 ranges in total. A 'range' is the collection of location data for an individual in any one tracking period. Simultaneous flock observations for $58 \%$ of ranges $/ 64 \%$ of individuals [61] indicated no unusual social behaviour by collared ewes. However, one core ewe was a member of a social group that chose to occupy a fenced exclosure which was under a different grazing regime to that of the study area (removed from analyses as explained below).

GPS collars (GPS_2200R, Lotek Wireless, Ontario, Canada) weighing $720 \mathrm{~g}$ were used to track ewes. Collars were programmed to record locations at 10-min intervals using scheduling software (GPSHOST, Lotek Engineering, Ontario, Canada) and current satellite almanac files from Lotek. Locations were stored onboard the collar and retrieved after 5 weeks. This was the maximum time taken for recordings to cease, either through battery pack expiry or data storage capacity (5028 differential locations) being reached [43].

Location data were downloaded to a PC and corrected to increase accuracy using post-differential correction software (N4, V.1.2138, Lotek Engineering, Ontario, Canada) and files from the nearest active base station $54 \mathrm{~km}$ distant (NUI Galway Base Station, Ordnance Survey Ireland, www.osi.ie). Post-differentially corrected GPS data have an accuracy of approximately $7 \mathrm{~m}$ radius [41]. Locations with a position dilution of precision value of more than 10 were excluded to further increase accuracy without excessive loss of GPS data [13, 42]. 


\section{Habitat condition and grazing lawn frequency surveys}

Habitat condition of the study area was originally mapped in 1999 [5] and groundtruthed for change in 2005. Assessment was made following the method described by [18] (now the National Parks and Wildlife Service) which uses six condition categories; undamaged, moderate-undamaged, moderately damaged, moderately-severely damaged, severely damaged and very severely damaged. These six categories are combined into three groups; undamaged, moderately damaged and severely damaged. Habitat condition indicators include but are not exclusive to grazing-related damage and are defined for each habitat type. Indicators include vegetation cover and growth, particularly the cover and condition of Calluna vulgaris (L.) Huds and the cover of Nardus stricta (L.), species richness, sward height, exposed soil and evidence of burning.

Grazing lawn frequencies were allocated for each complete or part 100x100 m grid square in 2005. Categories of grazing lawn patches $\left(\sim 4-7 \mathrm{~m}^{2}\right.$ or the equivalent area) were; (i) none, (ii) few (1-5 patches), (iii) several (6-10) and (iv) numerous/extensive $(>10)$. In the instance of a part grid square, on the boundary of the study area, it was classified as numerous/extensive if acid grassland occupied $\geq 0.3$ of its area.

The habitat condition and grazing lawn frequency maps were digitised using geographical information system software (ArcGIS Desktop, V.9.1, ESRI Inc., Redlands, CA, USA).

\section{Data analysis}

\section{Data handling}

Typically in wildlife tracking studies, animals are caught, tagged and released within their home range. However in this study, the flock was brought in from the study area, collars were fitted to selected ewes in an adjacent yard and then sheep were released from the yard and left to make their own way back to their chosen areas. To explore habitats selected by sheep and filter out data directly influenced by handling, the first 3 days after release were excluded. This 3-day period was chosen objectively by identifying core areas as $95 \%$ cores from inflections on cluster polygon incremental analysis plots [40] and scrutinising location data against $95 \%$ polygons to identify the time taken for sheep to leave the yard, reach a $95 \%$ polygon and stay there for longer than an overnight stop en route (taken as $11 \mathrm{~h} 51 \mathrm{~min}$, the annual mean non-daylight hours). The longest time taken by an individual was 2 days $23 \mathrm{~h}$, rounded to 3 days.

\section{Spatial and temporal autocorrelation of GPS data}

Locations from the same individual are not independent data, therefore tests for resource selection were based on summary statistics of resource use from the individual [38, 39] using compositional analysis. This allows comparison of both multiple individuals and resource categories in the same test [1]. Of the 36 ranges from nine tracking periods, 11 individuals were tracked and consequently 11 ranges (one per individual) were potentially suitable for compositional analysis. Range selection was made objectively, regardless of season, based on Minimum Convex Polygon (MCP) incremental analysis which is indicative of range stability [39], i.e. ranges where ewes were most settled were selected. Two individuals were omitted because; (a) dynamic interaction analyses [39] showed only two of 11 ranges were non-independent (Jacob's 
index was 0.769 based on geometric mean distances between same-time locations) so only one range (the most stable) of the pair was used and (b) one individual chose to occupy a fenced exclosure outside the study area that was under a different management regime, affecting resource classification. The final sample size was nine because (a) data that breach analysis assumptions of data independence or misrepresent typical habitat availability to the flock were rigorously omitted and (b) the cost of the tracking collars and replacement battery packs for each sampling period was a limiting factor. Sample sizes for seasonal tests differ and are explained below.

Ranges of individuals tracked in more than one season were suitable for separate seasonal tests. However, ranges were also included in seasonal analyses where the same individual was tracked for the same season for more than one sampling year. This may breach test assumptions of data independence but these ranges are included to minimise omission of data as independence could not be tested. Six of the original 36 ranges were omitted because the same individual repeatedly occupied an area outside the study area, and two further ranges were omitted as dynamic interaction analyses indicated that data (from three pairs of ranges consisting of three individuals and three ranges) were not independent (Jacob's index $>0.5$ ). Therefore, 28 ranges were suitable for seasonal tests.

\section{Datasets}

Seven datasets were produced in this study (Table 1). The 'Complete' dataset contained all post-processed data for the nine independent ewes. This dataset was then subdivided to form two additional datasets, 'Diurnal' and 'Nocturnal', based on mean sunrise and sunset times for each range. Seasonal datasets were produced that contained all post-processed data, excluding three days post-release, for 28 ranges divided between the four seasons.

Table 1. Composition of datasets

\begin{tabular}{|l|c|c|c|c|}
\hline \multicolumn{1}{|c|}{ Dataset } & $\begin{array}{c}\text { No. of } \\
\text { ranges }\end{array}$ & $\begin{array}{c}\text { No. of } \\
\text { individuals }\end{array}$ & $\begin{array}{c}\text { No. of years } \\
\text { sampled }\end{array}$ & $\begin{array}{c}\text { Total no. of } \\
\text { locations }\end{array}$ \\
\hline Complete & 9 & 9 & 3 & 21250 \\
\hline Diurnal & 9 & 9 & 3 & 11073 \\
\hline Nocturnal & 9 & 9 & 3 & 10177 \\
\hline Spring & 9 & 8 & 3 & 14353 \\
\hline Summer & 7 & 4 & 2 & 20967 \\
\hline Autumn & 6 & 3 & 2 & 17359 \\
\hline Winter & 6 & 3 & 2 & 15070 \\
\hline
\end{tabular}

\section{Range and resource analysis}

The tracked ewe location data, habitat condition map and grazing lawn frequency map were imported into range analysis software (Ranges7, Anatrack Ltd, Dorset, UK). MCPs were produced which link the outermost locations and are widely used as a broad estimate of animal ranges (e.g. [1]). The boundary of the study area, i.e. the area available to animals, was determined by a stockproof fence in this instance. Habitat condition and grazing lawn frequency analyses were performed using Ranges7 to estimate (i) the resource content of the study area, (ii) resource content of ranges (i.e. MCPs) and (iii) resource use at location. 


\section{Statistical analysis}

Selection of habitat condition and grazing lawn frequency categories was examined using weighted compositional analysis (Compos Analysis V.6.2+, Smith Ecology Ltd, Abergavenny, UK). Proportions of resource use were compared with those available, using Wilks' lambda $(\Lambda)$ test (MANOVA). Analyses were carried out at two selection levels based on selection levels identified by [36]:

(i)

broad, comparing proportions of resources present within ewe ranges with those available in the study area accessible to sheep, and

(ii) detailed, comparing proportions of resources used at location with those available within individual ewe ranges.

It is unlikely that resource use and available percentage data follow a multivariate normal distribution, hence randomisation tests were used to evaluate the significance of $\Lambda$ and t values [1].

\section{Results}

\section{Ewe locations}

Most occupation during day, night and year-round was in the northwest quarter of the study area (Figs 1, 2). Nocturnal locations were distinctly more clustered than diurnal locations (Fig. 1b, c). While seasonal distribution patterns could not be compared in this instance because the individuals tracked and number of individuals and ranges differ (Table 1), Figure 2 indicates a tendency towards seasonal variation. 
a) Complete dataset with diurnal and nocturnal locations combined

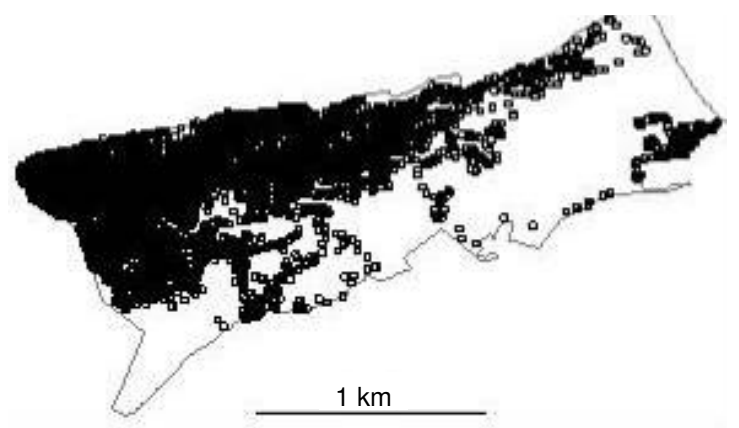

b) Diurnal dataset
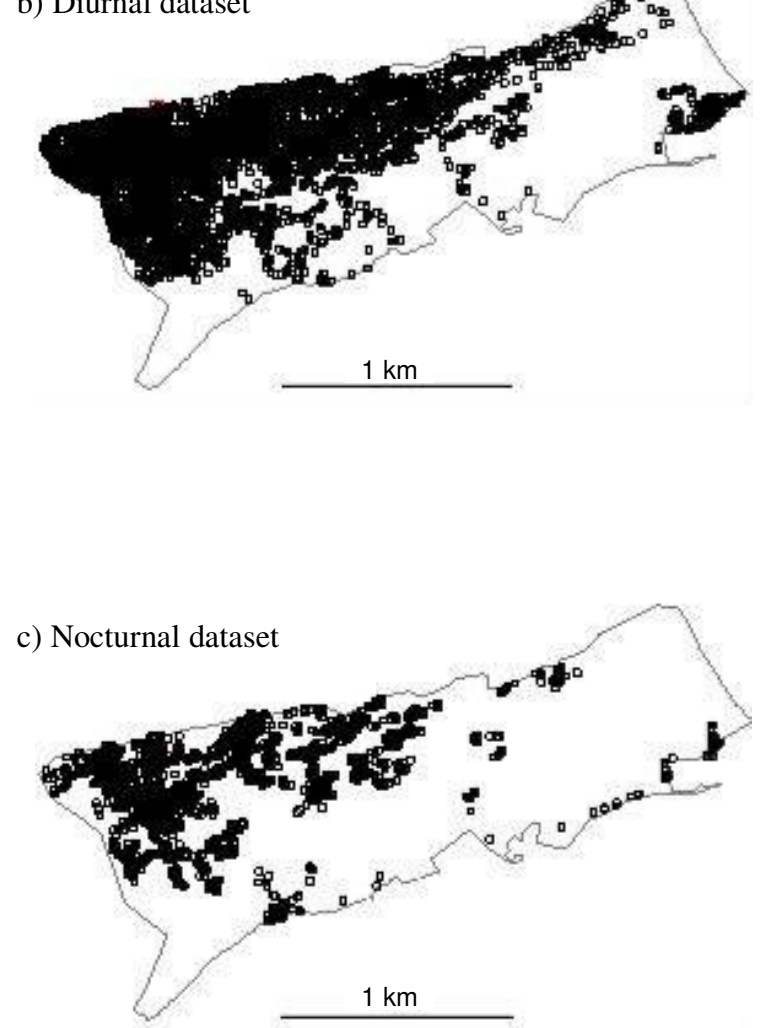

Figure 1. Location data of nine ewes tracked between February 2004 and April 2006 using GPS collars. 

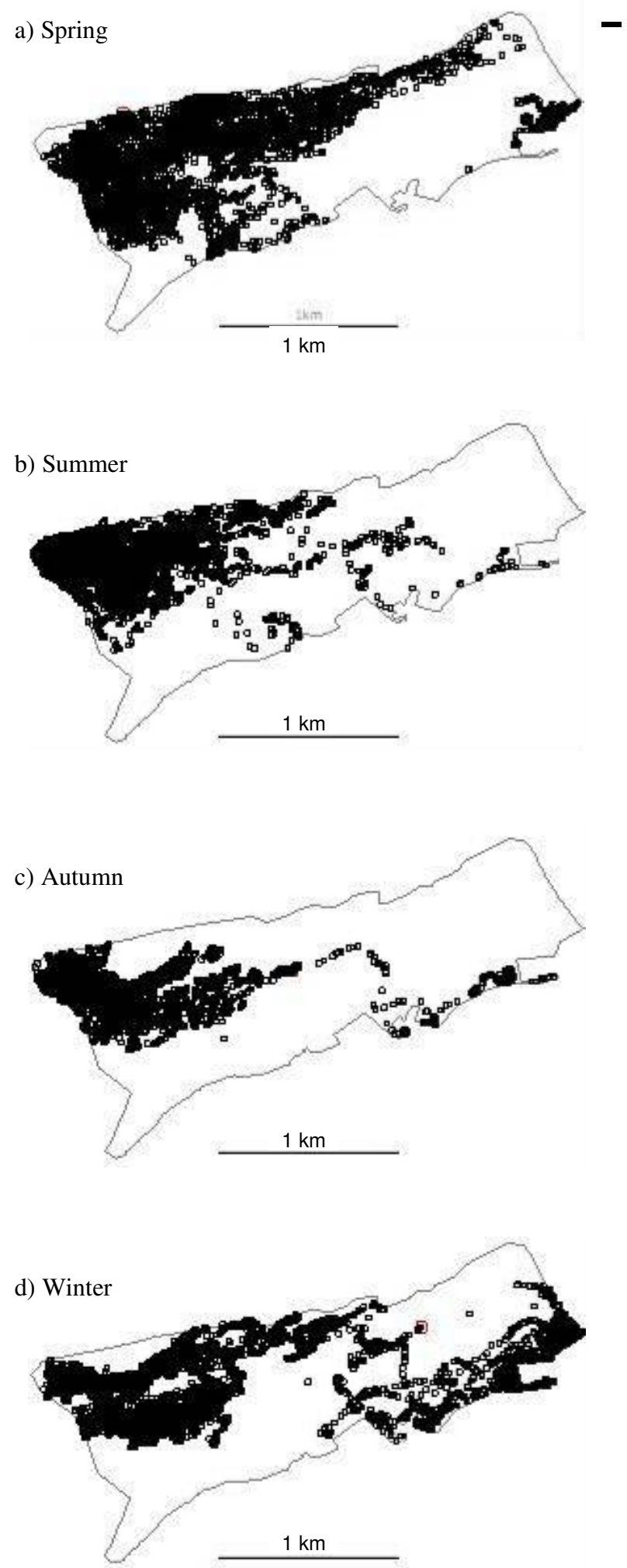

Figure 2. Seasonal location data of ewes tracked between February 2004 and April 2006 using GPS collars. 


\section{Grazing lawn frequency}

The dominant categories of grazing lawn frequency available across the study area were few (36.8\%) and numerous/extensive (34.3\%), (Table 2a). Distribution of grazing lawns was clearly uneven with the most numerous/extensive occurring in the northwest corner (Fig. 3). Use was significantly non-random $(P<0.05)$ with numerous/extensive patches consistently selected most at broad and detailed selection levels, day and night, and across all four seasons (Table 3). There was slight variation in sequences of the subsequent three ranks between broad and detailed selection levels (Table 3), day and night (Table $3 a, b)$, summer and the other three seasons at the broad level (Table 3c), and between autumn and the other three seasons at the detailed level (Table 3d). 'None' was consistently selected least at the broad level for all seven datasets (Table $3 a, c)$ but mostly this was not the case at the detailed level (Table $3 b, d$ ).

Table 2. Availability of grazing lawns and habitat conditions in the 216.9 ha study area.

\begin{tabular}{|l|l|l|}
\hline \multicolumn{1}{|c|}{ Category } & \% available & \multicolumn{1}{c|}{ Group } \\
\hline a) Grazing lawn frequency & 11.4 & n/a \\
\hline None & 36.8 & n/a \\
\hline Few (0-5) & 17.4 & n/a \\
\hline Several (6-10) & 34.3 & n/a \\
\hline Numerous (>10)/extensive & 29.5 & Undamaged (U) \\
\hline b) Habitat conditions & 22.3 & Moderately damaged (M) \\
\hline Undamaged (U) & 21.0 & Moderately damaged (M) \\
\hline Moderate-undamaged (MU) & 5.5 & Moderately damaged (M) \\
\hline Moderately damaged (M) & 2.0 & Severely damaged (S) \\
\hline Moderate-severely damaged (MS) & 19.8 & Severely damaged (S) \\
\hline Severely damaged (S) &
\end{tabular}

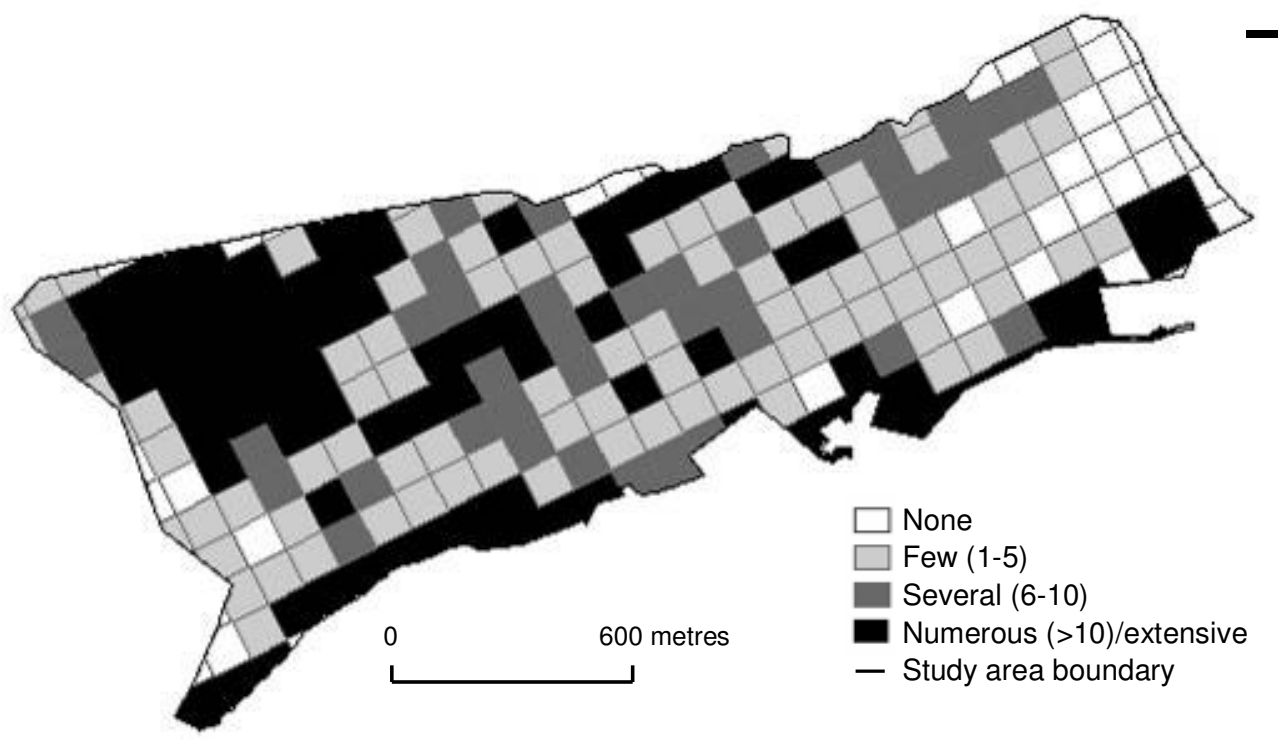

Figure 3. Distribution of grazing lawns by grid square. 
Table 3. Tests for random use, by Scottish Blackface hill sheep, of grid squares consisting of varying grazing lawn frequencies. The grazing lawn frequency ranking is shown in parentheses when $\Lambda$ is not significant and '>>>' denotes a significant difference between two consecutively ranked frequency categories.

\begin{tabular}{|c|c|c|c|c|}
\hline Dataset & $\begin{array}{c}\text { Rand } \\
\Lambda\end{array}$ & $\begin{array}{r}\text { mess test } \\
P\end{array}$ & $\begin{array}{c}\text { Grazing lawn frequency rankings } \\
\text { (most>least selected) }\end{array}$ & $\begin{array}{c}\% \text { of } \\
\text { total } \\
\text { locations }\end{array}$ \\
\hline \multicolumn{5}{|c|}{ a) Nine individuals, broad selection level ( $\mathrm{MCP}^{\mathrm{a}}$ vs. study area) } \\
\hline Complete & 0.293 & $0.015 *$ & Numerous $\gg>>$ several $>$ few $\gg>>$ none & 100.0 \\
\hline Diurnal & 0.270 & $0.005 * *$ & Numerous $>>>$ several $>$ few $\gg>>$ none & 100.0 \\
\hline Nocturnal & 0.280 & $0.003 * *$ & Numerous $\gg \gg>$ few $>$ several $>$ none & 100.0 \\
\hline \multicolumn{5}{|c|}{ b) Nine individuals, detailed selection level (locations vs. MCP) } \\
\hline Complete & 0.111 & $0.005 * *$ & Numerous $>$ none $>$ several $>$ few & 100.0 \\
\hline Diurnal & 0.138 & $0.027 *$ & Numerous $>$ none $>$ several $>$ few & 100.0 \\
\hline Nocturnal & 0.187 & $0.006 * *$ & Numerous $>>>$ several $>$ none $>$ few & 100.0 \\
\hline \multicolumn{5}{|c|}{ c) Seasonal use, broad selection level (MCP vs. study area) } \\
\hline Spring & 0.237 & $0.006 * *$ & Numerous $\gg>>$ few $>$ several $\gg>>$ none & 100.0 \\
\hline Summer & 0.021 & $0.042 *$ & Numerous $\gg>>$ several $>$ few $\gg>>$ none & 100.0 \\
\hline Autumn & 0.189 & 0.127 & (Numerous $>$ few $>$ several $>>>$ none) & 100.0 \\
\hline Winter & 0.362 & 0.285 & (Numerous $>$ few $>$ several $>>>$ none) & 100.0 \\
\hline \multicolumn{5}{|c|}{ d) Seasonal use, detailed selection level (locations vs. MCP) } \\
\hline Spring & 0.149 & $0.036 *$ & Numerous $>$ none $>$ several $>$ few & 100.0 \\
\hline Summer & 0.185 & 0.116 & (Numerous $>$ none $>$ several $>$ few) & 100.0 \\
\hline Autumn & 0.059 & $0.026 *$ & Numerous $>$ several $>$ few $>$ none & 100.0 \\
\hline Winter & 0.151 & 0.185 & (Numerous $>$ none $>$ several $>$ few $)$ & 100.0 \\
\hline
\end{tabular}

\section{Habitat condition}

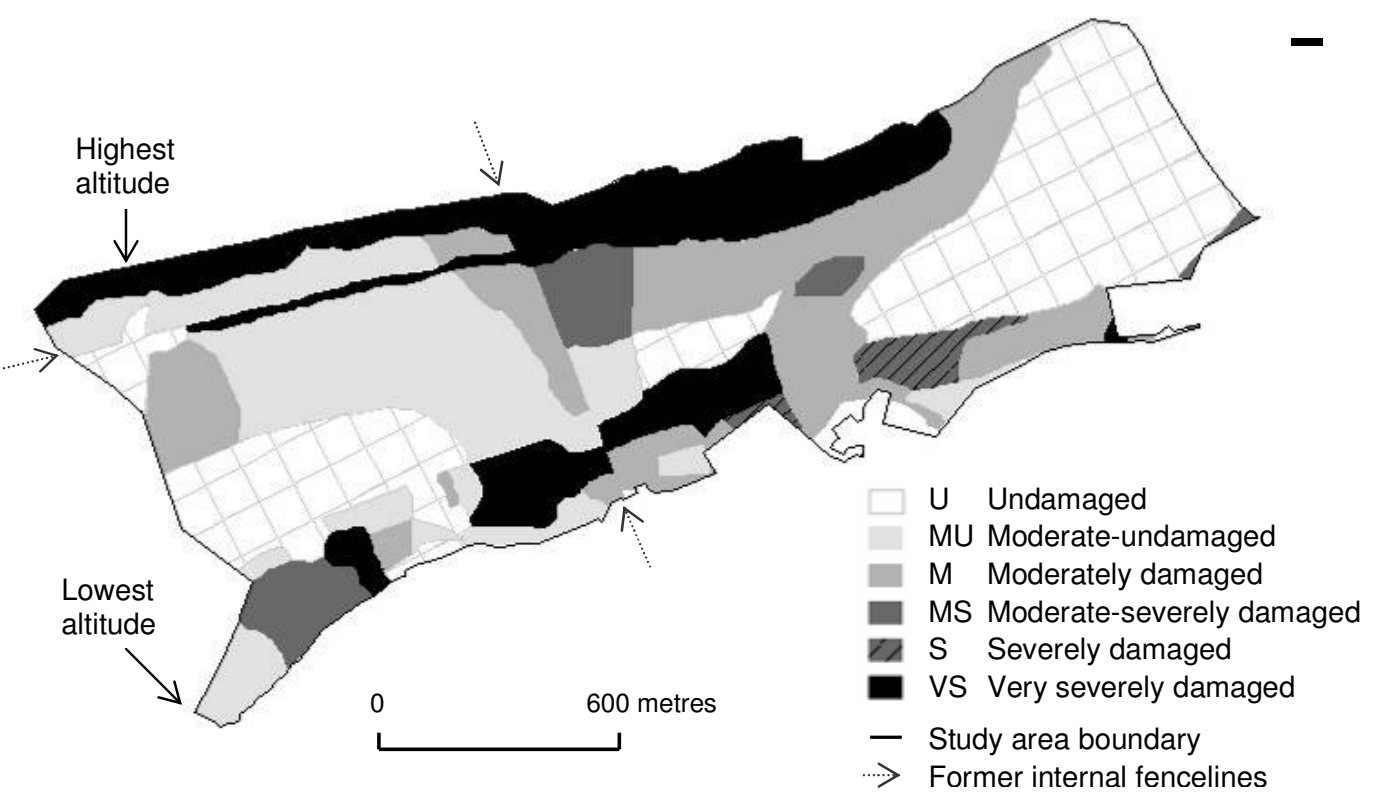

Figure 4. Habitat condition map of the study area. 
All six categories of habitat condition, from undamaged to very severely damaged, occurred across the study area (Table 2b, Fig. 4). The most severe damage was associated mainly with blanket bog on the mountain ridge (northern boundary) and also, in places, at low altitude (Fig. 4). Two former internal fencelines were evident on the habitat condition map. An initial visual comparison between the sheep occupation and habitat condition figures suggested that the most abundant habitat condition in the northwest quarter of the study area, where sheep occupation tended to be concentrated, was moderately damaged.

Use of habitat condition categories was random for 20 of 28 tests which suggests that selection by ewes was not significant $(P>0.05)$, (Table 4,5$)$. Nevertheless, rank sequences are still thought to be meaningful [61]. The moderate-undamaged category was consistently selected most at the broad and detailed levels, day and night, and across all seasons with the exception of autumn at the detailed level where it was the second-most selected category (Table 4a, $b$; Table 5a, b). Very severely damaged areas were second-most selected with nine ewes at the broad level and in summer at both levels (Table 4a; Table 5a, b), selected least for the remaining three seasons at the detailed level (Table $5 b$ ), of intermediate ranks at the detailed level with nine ewes (Table $4 b)$ and of various ranks for seasons at the broad level (Table 5a). Undamaged areas were selected considerably more within ewe ranges by day than at night when they were selected least (Table 4b).

Table 4. Tests for random use of habitat condition categories by nine individual Scottish Blackface hill sheep based on three datasets. The habitat condition ranking is shown in parentheses when $\Lambda$ is not significant and ' $>>>$ ' denotes a significant difference between two consecutively ranked condition categories.

\begin{tabular}{|c|c|c|c|c|}
\hline \multirow[t]{2}{*}{ Dataset } & \multicolumn{2}{|c|}{ Randomness test } & \multirow{2}{*}{$\begin{array}{l}\text { Habitat condition rankings } \\
\quad(\text { most>least selected })^{\mathrm{a}}\end{array}$} & \multirow{2}{*}{$\begin{array}{l}\% \text { of total } \\
\text { locations }\end{array}$} \\
\hline & $\Lambda$ & $\boldsymbol{P}$ & & \\
\hline \multicolumn{5}{|c|}{ a) Broad selection level $\left(\mathrm{MCP}^{\mathrm{b}}\right.$ vs. study area) with all six categories } \\
\hline Complete & 0.266 & 0.172 & $(\mathrm{MU}>\mathrm{VS}>\mathrm{M}>\mathrm{MS}>\mathrm{U}>\mathrm{S})$ & 100.0 \\
\hline Diurnal & 0.156 & $0.033 *$ & $\mathrm{MU}>\mathrm{VS}>\mathrm{M}>\mathrm{MS}>\mathrm{U}>\mathrm{S}$ & 100.0 \\
\hline Nocturnal & 0.217 & 0.120 & $(\mathrm{MU}>\mathrm{VS}>\mathrm{M}>\mathrm{MS}>\mathrm{S}>\mathrm{U})$ & 100.0 \\
\hline \multicolumn{5}{|c|}{ b) Detailed selection level (locations vs. MCP) with all six categories } \\
\hline Complete & 0.000 & 0.065 & $(\mathrm{MU}>\mathrm{M}>\mathrm{VS}>\mathrm{U}>\mathrm{MS}>\mathrm{S})$ & 100.0 \\
\hline Diurnal & 0.005 & $0.023 *$ & $\mathrm{MU}>\mathrm{U}>\mathrm{M}>\mathrm{VS}>\mathrm{MS}>\mathrm{S}$ & 100.0 \\
\hline Nocturnal & 0.000 & $0.032 *$ & $\mathrm{MU}>\mathrm{M}>\mathrm{VS}>\mathrm{MS}>\mathrm{U}>\mathrm{S}$ & 100.0 \\
\hline \multicolumn{5}{|c|}{ c) Broad selection level ( $\mathrm{MCP}^{\mathrm{b}}$ vs. study area) with three condition groups } \\
\hline Complete & 0.535 & 0.104 & $(\mathrm{M}>\mathrm{S}>>>\mathrm{U})$ & 100.0 \\
\hline Diurnal & 0.547 & 0.114 & $(\mathrm{M}>\mathrm{S}>>>\mathrm{U})$ & 100.0 \\
\hline Nocturnal & 0.391 & $0.045 *$ & $\mathrm{M}>\mathrm{S}>>>\mathrm{U}$ & 100.0 \\
\hline \multicolumn{5}{|c|}{ d) Detailed selection level (locations vs. MCP) with three condition groups } \\
\hline Complete & 0.312 & $0.030 *$ & $\mathrm{M}>\mathrm{S}>\mathrm{U}$ & 100.0 \\
\hline Diurnal & 0.456 & 0.105 & $(\mathrm{M}>\mathrm{U}>\mathrm{S})$ & 100.0 \\
\hline Nocturnal & 0.650 & 0.672 & $(\mathrm{M}>\mathrm{U}>\mathrm{S})$ & 100.0 \\
\hline
\end{tabular}

${ }^{\mathrm{a}} \mathrm{U}=$ Undamaged area, $\mathrm{MU}=$ Moderate-Undamaged area, $\mathrm{M}=$ Moderately damaged area, $\mathrm{MS}=$ Moderate-Severely damaged area, $\mathrm{S}=$ Severely damaged area, VS = Very Severely damaged area. ${ }^{\mathrm{b}} \mathrm{MCP}=$ Minimum Convex Polygon, used to estimate ewe ranges.

Severely damaged and moderate-severely damaged categories were omitted from seasonal analyses at the detailed level (Table $5 b$ ) because low use prohibited analyses 
from running, hence tests were repeated with data for all six categories combined into three condition groups (Table 2). Consistent with findings using six categories where moderate-undamaged was generally most selected, the moderately damaged group was selected most at both selection levels, day, night and year-round except in summer at the broad selection level when severely damaged areas were most selected (Table $4 c, d$; Table 5c, $d$ ).

Table 5. Seasonal tests for random use of habitat condition categories by Scottish Blackface hill sheep. The habitat condition ranking is shown in parentheses when $\Lambda$ is not significant and '>>>' denotes a significant difference between two consecutively ranked condition categories.

\begin{tabular}{|c|c|c|c|c|}
\hline Dataset & \multicolumn{2}{|c|}{ Randomness test } & $\begin{array}{l}\text { Habitat condition rankings } \\
\quad(\text { most }>\text { least selected })^{\mathrm{a}}\end{array}$ & $\begin{array}{l}\% \text { of total } \\
\text { locations }\end{array}$ \\
\hline \multicolumn{5}{|c|}{ a) Broad selection level $\left(\mathrm{MCP}^{\mathrm{b}}\right.$ vs. study area) with all six categories } \\
\hline Spring & 0.105 & 0.066 & $(\mathrm{MU}>\mathrm{M}>\mathrm{VS}>\mathrm{U}>\mathrm{MS}>\mathrm{S})$ & 100.0 \\
\hline Summer & 0.004 & 0.067 & $(\mathrm{MU}>\mathrm{VS}>>>\mathrm{U}>\mathrm{M}>\mathrm{S}>\mathrm{MS})$ & 100.0 \\
\hline Autumn & 0.000 & $0.031 *$ & $\mathrm{MU} \gg>\mathrm{U}>\mathrm{M}>\mathrm{VS}>\mathrm{S}>>>\mathrm{MS}$ & 100.0 \\
\hline Winter & 0.047 & 0.318 & $(\mathrm{MU}>\mathrm{M}>>>\mathrm{U}>\mathrm{MS}>\mathrm{VS}>\mathrm{S})$ & 100.0 \\
\hline \multicolumn{5}{|c|}{ b) Detailed selection level (locations vs. MCP) with all six categories } \\
\hline Spring & 0.296 & 0.179 & $(\mathrm{MU}>\mathrm{M}>\mathrm{U}>\mathrm{VS})$ & 100.0 \\
\hline Summer & 0.255 & 0.164 & $(\mathrm{MU}>\mathrm{VS}>\mathrm{M}>\mathrm{U})$ & 100.0 \\
\hline Autumn & 0.198 & 0.283 & $(\mathrm{U}>\mathrm{MU}>\mathrm{M}>\mathrm{VS})$ & 100.0 \\
\hline Winter & 0.434 & 0.448 & $(\mathrm{MU}>\mathrm{M}>\mathrm{U}>\mathrm{VS})$ & 100.0 \\
\hline \multicolumn{5}{|c|}{ c) Broad selection level (MCP vs. study area) with three condition groups } \\
\hline Spring & 0.431 & $0.013 *$ & $\mathrm{M} \gg>>\mathrm{S}>\mathrm{U}$ & 100.0 \\
\hline Summer & 0.404 & 0.095 & $(\mathrm{~S}>\mathrm{M}>>>\mathrm{U})$ & 100.0 \\
\hline Autumn & 0.244 & 0.082 & $(\mathrm{M} \gg>>\mathrm{U}>\mathrm{S})$ & 100.0 \\
\hline Winter & 0.442 & $0.028 *$ & $\mathrm{M}>\mathrm{U}>\mathrm{S}$ & 100.0 \\
\hline \multicolumn{5}{|c|}{ d) Detailed selection level (locations vs. MCP) with three condition groups } \\
\hline Spring & 0.346 & 0.151 & $(\mathrm{M}>\mathrm{U}>\mathrm{S})$ & 100.0 \\
\hline Summer & 0.565 & 0.286 & $(\mathrm{M}>\mathrm{S}>\mathrm{U})$ & 100.0 \\
\hline Autumn & 0.198 & 0.070 & $(\mathrm{M}>\mathrm{U}>\mathrm{S})$ & 100.0 \\
\hline Winter & 0.304 & 0.168 & $(\mathrm{M}>\mathrm{U}>\mathrm{S})$ & 100.0 \\
\hline
\end{tabular}

${ }^{\mathrm{a}} \mathrm{U}=$ Undamaged area, $\mathrm{MU}=$ Moderate-Undamaged area, $\mathrm{M}=$ Moderately damaged area, $\mathrm{MS}=$

Moderate-Severely damaged area, $\mathrm{S}=$ Severely damaged area, VS = Very Severely damaged area.

${ }^{\mathrm{b}} \mathrm{MCP}=$ Minimum Convex Polygon, used to estimate ewe ranges.

\section{Discussion}

\section{Sheep distribution}

Sheep occupation being concentrated in the northwest quarter of the study area is probably attributable directly and indirectly to topography with the highest elevation, steep slopes, shelter-providing bowl-like features, shallower and better-drained soils and the most extensive patches of relatively better forage quality and availability than elsewhere in the area $[4,17,57,61]$.

Nocturnal GPS location data were more clustered than diurnal locations which was expected as sheep are well known to be active mostly during daylight hours and to rest at night [20, 59, 61]. Whilst sheep of other breeds have been reported to usually congregate in the same places at night [3], Scottish Blackface individuals do not return 
to the same place every night [31]. This is consistent with this study's findings of multiple nocturnal rest sites for nine tracked individuals (Fig. 1c). This probably does not have implications for management because, although occupying different nocturnal rest sites implies dispersal was greater than if sheep returned to the same sites, individuals have been found to occupy just 9-20\% of this study area [61].

\section{Grazing lawn frequency}

Grid squares with numerous/extensive grazing lawns were associated with a range of features, i.e. a large bowl-like feature and adjacent hillock in the northwest corner, the riverbank on the western half of the southern boundary, farm tracks and earth banks along the eastern half of the southern boundary, and scattered hillocks, rock outcrops and/or sloping ground with relatively well-drained soils. Absence of grazing lawns was typically associated with areas of waterlogged, deep, quaking peat on relatively level ground, and occasionally with very steep north-facing slopes inaccessible to sheep on the northern boundary.

The most extensive grazing lawns were found in the northwest of the study area which correlates with sheep occupation patterns. Numerous/extensive patches were consistently selected most, probably because acid grassland habitats are preferred most by sheep on hills $[12,60,61]$ and are a product of heavy grazing $[25,45]$.

Sheep most selected grid squares containing numerous/extensive grazing lawns even in winter which is inconsistent with possible expectations from reviewing literature as resources on favoured patches deplete after the growing season [35] and grazing lawns on this study site were previously found to be dominated by Molinia caerulea [51] which dies back in early autumn. Selection in winter of grid squares with numerous/extensive grazing lawns is probably explained by Scottish Blackface sheep being known to return to home ranges that are learned from dams [32] and to graze in close proximity to grassland patches [12]. Sheep were probably utilising alternative habitats as grid squares that contained numerous/extensive grazing lawns usually supported and may have been dominated by different habitats, particularly wet heath.

\section{Habitat condition}

Wind-driven rain and its effect on soil erosion is reported to be most severe close to the top of a hill [11], and this probably contributed to much of the damage associated with the mountain ridge along the northern boundary of the study site. The thin strip of severely damaged habitats running parallel to this in the northwest quarter marked a former fenceline (that was removed in 2001) along which poaching and sheep paths were observed, where sheep traversed the hill between shelter-providing bowl-like features dominated by acid grassland. Two severely damaged compartments on the southern boundary were associated with deep peat, relatively level ground, waterlogging most of the year, former peat extraction in places and routes habitually taken when sheep were gathered and released from the yard.

Grazers can facilitate damage to upland habitats, conversely, they increase diversity in plant species composition and structure and the fauna this supports [55]. For this reason, and because habitat condition assessment took flora diversity into account, the northwest area most occupied by sheep was predominantly classified as undamaged to moderately damaged. While increasing diversity has ecological benefits, acid grassland patches replace wet heath $[27,56,57]$ which, unlike acid grassland, is listed under 
Annex I of the Habitats Directive. Some acid grassland is desirable but the spread of grassland patches is likely and poses a threat to heathland communities [12].

Use of areas with differing categories of habitat condition was mostly random, which indicates there was not a direct correlation between sheep occupation and habitat condition. This is partly attributable to other factors of erosion that are not grazingrelated and partly because the carrying capacity of different plant communities and topography vary. It is speculated that the main reasons are diet selection as discussed below and that the mapping accuracy of vegetation condition (following the guidelines) is much lower than that of the GPS location data. Additionally, a limitation of this study is that it is based on detailed information from only a small number of individuals, causing low power in statistical tests. However, this study justifies further research with larger sample sizes.

Findings that support possible expectations that use of damaged areas by sheep would be low include the selection ranking being lowest for very severely damaged areas in all seasons except summer and highest for moderate-undamaged areas in all seasons. Conversely, very severely damaged areas had the second-highest selection rank in several tests, and most tests for habitat condition selection were not significant $(P>0.05)$, suggesting that sheep did not avoid damaged areas.

Very severely damaged areas had the second-highest selection rank in summer at both selection levels and the severely damaged condition group was most selected at the broad selection level in summer. This is consistent with the notion that hill sheep like the 'bare bite', i.e. sheep graze bare areas despite the availability of lush vegetation patches. This could be explained by selective grazing for preferred species during the growing season as [30] reported high proportions of Narthecium ossifragum (L.) Huds and Eriophorum spp. (L.) in the diets of Scottish Blackface sheep grazing blanket bog, and these species were dominant on areas of exposed peat (i.e. severely damaged areas) in this study.

\section{Implications for conservation}

Based on the finding that sheep consistently selected grid squares containing numerous/extensive grazing lawns, an efficient indicator of hill use by sheep would be to map acid grassland frequency following the simple method introduced in this study. This could have a secondary purpose of identifying areas of wet or dry heath most at risk of grazing-related damage, as most heather damage is known to occur within $5 \mathrm{~m}$ of grassland patch edges [12]. Grazing lawns contribute to the biodiversity value of a site [53] but are a threat to heathland communities that have been identified as being more important for conservation [21]. Determining correct stock numbers and management practices are crucial to prevent an increase in the number or extent of grazing lawns and to meet conservation objectives. Limits of acceptable change should be set for the proportion of grazing lawns and the extent of grazing lawns should be monitored.

The full spectrum of habitat conditions from undamaged to very severely damaged areas occurring on one site, combined with uneven use by grazers with unlimited access, supports the widely held belief that a single stocking rate for upland and peatland sites is inadequate. Stocking rate calculations need to be based on relative proportions of habitats available and habitat condition, as recognised by [49], and habitat selection exhibited by grazers [61]. In light of grazer distribution not corresponding directly to habitat conditions, stocking rates calculated at site level are 
probably still not enough to arrest and reverse grazing-related damage because areas of different categories of habitat condition require different action.

Various recommendations have been made to arrest damage to vegetation and promote recovery. A reduction in sheep numbers is often recommended [3, 7, 34]. Additional recommendations include sheep exclusion from severely damaged areas until vegetation has recovered $[8,54]$, cutting thrice-yearly of undamaged, but arguably undergrazed, Molinia caerulea (L.) Moench-dominant areas to promote recovery by Calluna vulgaris (L.) Hull [47] and mixed grazing of cattle or goats with sheep [10,33]. However, cutting would not be a practical option on a site such as that studied with deep peats and steep slopes prohibiting tractor access, and grazing cattle would need to be restricted to periods when water levels are low to minimise poaching by heavier animals. Benefits from allowing vegetation to recover would include improved ecological, landscape and livestock production quality.

To conclude, a comprehensive understanding of resource use by grazers is fundamental in designing conservation strategies and management planning should consider habitat condition and grazer distribution as previously recognised. This study presents an efficient method for realising this objective, based on hill sheep selection of grid squares containing higher frequencies of grazing lawns. Use of very severely damaged areas was greatest in summer during the plant growing season and therefore inhibiting vegetation recovery. Temporary exclusion of livestock or reducing stocking rates during this season would facilitate an improvement in habitat condition. However, management recommendations cannot be inferred beyond the study area without further research on a number of sampling sites and with different habitat condition assemblages. The methods presented, including the rapid mapping of grazing lawn frequency introduced in this study and easily collecting vast, accurate data using GPS devices, are recommended for use in such studies in the future.

Acknowledgements Thanks to Teagasc for funding this research under the Walsh Fellowship Scheme and the following for their assistance; Luke O’Malley, PJ Hastings, J.P. Hanrahan, Rod Green, John Warren, James Moran, Niamh Quinn and Juan Carlos Castaneda.

\section{REFERENCES}

[1] Aebischer, N.J., Robertson, P.A., Kenward, R.E. (1993): Compositional analysis of habitat use from animal radio-tracking data. - Ecology 74: 1313-1325.

[2] Armstrong, H.M., Gordon, I.J., Hutchings, N.J., Illius, A.W., Milne, J.A., Sibbald, A.R. (1997): A model of the grazing of hill vegetation by sheep in the UK. II. The prediction of offtake by sheep. - Journal of Applied Ecology 34: 186-207.

[3] Bakker, J.P., de Bie, S., Dallinga, J.H., Tjaden, P., de Vries, Y. (1983): Sheep-grazing as a management tool for heathland conservation and regeneration in the Netherlands. Journal of Applied Ecology 20: 541-560.

[4] Berggren-Thomas, B., Hohenboken, W.D. (1986): The effects of sire-breed, forage availability and weather on the grazing behavior of crossbred ewes. - Applied Animal Behaviour Science 15: 217-228.

[5] Bleasdale, A., Heffron, J. (1999): A Vegetation Condition Assessment of the Teagasc Hill Sheep Farm, Erriff, Co. Mayo. - Dúchas and Department of Agriculture and Food, Dublin.

[6] Bleasdale, A., Sheehy Skeffington, M. (1992): The influence of agricultural practices on plant communities in Connemara. - In: Feehan, J. (ed.) Environment and Development in Ireland, University College Dublin, Dublin. 
[7] Bleasdale, A., Sheehy Skeffington, M. (1995): The upland vegetation of north-east Connemara in relation to sheep grazing. - In: Jeffrey, D.W., Jones, M.B., McAdam, J.H. (eds.) Irish Grasslands: Their Biology and Management, Royal Irish Academy, Dublin.

[8] Britton, A.J., Pearce, I.S.K., Jones, B. (2005): Impacts of grazing on montane heath vegetation in Wales and implications for the restoration of montane areas. - Biological Conservation 125: 515-524.

[9] Cadbury, C.J. (1987): Moorland birds - Britain's international responsibility. - In: Cadbury, C.J., Everett, M. (eds.) RSPB Conservation Review 1987, Royal Society for the Protection of Birds, Sandy.

[10] Celaya, R., Oliván, M., Ferreira, L.M.M., Martínez, A., García, U., Osoro, K. (2007): Comparison of grazing behaviour, dietary overlap and performance in non-lactating domestic ruminants grazing on marginal heathland areas. - Livestock Science 106: 271281.

[11] Choi, E.C.C. (2002): Modelling of wind-driven rain and its soil detachment effect on hill slopes. - Journal of Wind Engineering and Industrial Aerodynamics 90: 1081-1097.

[12] Clarke, J.L., Welch, D., Gordon, I.J. (1995): The influence of vegetation pattern on the grazing of heather moorland by red deer and sheep. I. The location of animals on grass/heather mosaics. - Journal of Applied Ecology 32: 166-176.

[13] D'Eon, R.G., Delparte, D. (2005): Effects of radio-collar position and orientation on GPS radio-collar performance, and the implications of PDOP in data screening. - Journal of Applied Ecology 42: 383-388.

[14] Defra (2007): Environmental protection. <www.defra.gov.uk/environment/index.htm> [Last accessed November 2007].

[15] Dennis, P., Skartveit, J., McCracken, D.I., Pakeman, R.J., Beaton, K., Kunaver, A., Evans, D.M. (2008): The effects of livestock grazing on foliar arthropods associated with bird diet in upland grasslands of Scotland. - Journal of Applied Ecology 45: 279-287.

[16] Department of Arts Heritage Gaeltacht and the Islands (2002): National Biodiversity Plan. - Government of Ireland, Dublin.

[17] Doyle, G.J. (1982): The vegetation, ecology and productivity of Atlantic blanket bog in Mayo and Galway, western Ireland. - Journal of Life Sciences Royal Dublin Society 3: 147-164.

[18] Dúchas the Heritage Service, the Department of Agriculture and Food (1999): A Manual for the Production of Grazing Impact Assessments in Upland and Peatland Habitats. Dúchas the Heritage Service \& the Department of Agriculture and Food, Dublin.

[19] Dumont, B., Boissy, A. (2000): Grazing behaviour of sheep in a situation of conflict between feeding and social motivations. - Behavioural Processes 49: 131-138.

[20] England, G.J. (1954): Observations on the grazing behaviour of different breeds of sheep at Pantyrhaud Farm, Carmarthenshire. - British Journal of Animal Behaviour 2: 56-60.

[21] European Commission (2007): EU Nature Legislation. <http://ec.europa.eu/ environment/nature/legislation/index_en.htm> [Last accessed November 2007].

[22] European Environmental Advisory Councils (1999): Annex: Agriculture and environment in eight European countries. <http://www.eeac-net.org/workgroups/pdf/WGAgriculture_ Agenda200_Proposals_1999_Annex.pdf> [Last accessed May 2007].

[23] Evans, D.M., Redpath, S.M., Elston, D.A., Evans, S.A., Mitchell, R.J., Dennis, P. (2006): To graze or not to graze? Sheep, voles, forestry and nature conservation in the British uplands. - Journal of Applied Ecology 43: 499-505.

[24] Fenton, E.W. (1937): The influence of sheep on the vegetation of hill grazings in Scotland. - Journal of Ecology 25: 424-430.

[25] Fossitt, J.A. (2000): A Guide to Habitats in Ireland. - The Heritage Council, Kilkenny.

[26] Gardiner, M.J., Radford, T. (1980): Soil Associations of Ireland and their Land Use Potential. Soil Survey Bulletin No. 36 -An Foras Talúntais, Dublin.

[27] Gillmor, D.A., Walsh, J.A. (1993): County-level variations in agricultural adjustment in Ireland in the 1980s. - Geographical Viewpoint 21: 25-44. 
[28] Ginane, C., Dumont, B. (2006): Generalization of conditioned food aversions in grazing sheep and its implications for food categorization. - Behavioural Processes 73: 178-186.

[29] Grant, S.A., Bolton, G.R., Torvell, L. (1985): The responses of blanket bog vegetation to controlled grazing by hill sheep. - Journal of Applied Ecology 22: 739-751.

[30] Grant, S.A., Torvell, L., Smith, H.K., Suckling, D.E., Forbes, T.D.A., Hodgson, J. (1987): Comparative studies of diet selection by sheep and cattle: blanket bog and heather moor. - Journal of Ecology 75: 947-960.

[31] Hewson, R., Verkaik, A.J. (1981): Body condition and ranging behaviour of Blackface hill sheep in relation to lamb survival. - Journal of Applied Ecology 18: 401-415.

[32] Hewson, R., Wilson, C.J. (1979): Home range and movements of Scottish Blackface sheep in Lochaber, north-west Scotland. - Journal of Applied Ecology 16: 743-751.

[33] Hodgson, J., Forbes, T.D.A., Armstrong, R.H., Beattie, M.M., Hunter, E.A. (1991): Comparative studies of the ingestive behaviour and herbage intake of sheep and cattle grazing indigenous hill plant communities. - Journal of Applied Ecology 28: 205-227.

[34] Hulme, P.D., Merrell, B.G., Torvell, L., Fisher, J.M., Small, J.L., Pakeman, R.J. (2002): Rehabilitation of degraded Calluna vulgaris (L.) Hull-dominated wet heath by controlled sheep grazing. - Biological Conservation 107: 351-363.

[35] Hunter, R.F. (1962): Hill sheep and their pasture: a study of sheep-grazing in south-east Scotland. - Journal of Ecology 50: 651-680.

[36] Johnson, D.H. (1980): The comparison of usage and availability measurements for evaluating resource preference. - Ecology 61: 65-71.

[37] Joint Nature Conservation Committee (2007): UK Biodiversity Action Plan. $<$ www.ukbap.org.uk> [Last accessed December 2007].

[38] Kenward, R.E. (1992): Quantity versus quality: programmed collection and analysis of radio-tracking data. - In: Priede, I.G., Swift, S.M. (eds.) Wildlife Telemetry: Remote Monitoring and Tracking of Animals, Ellis Horwood, Chichester.

[39] Kenward, R.E. (2001): A Manual for Wildlife Radio Tagging. - Academic Press, London.

[40] Kenward, R.E., Clarke, R.T., Hodder, K.H., Walls, S.S. (2001): Density and linkage estimators of home range: nearest-neighbor clustering defines multinuclear cores. Ecology 82: 1905-1920.

[41] Lotek Wireless (2000): N4 Differential Post-processing Software Users' Manual. - Lotek Wireless, Ontario.

[42] Lotek Wireless (2001): Small Animal GPS Location System: User's Manual: GPS 2000 Series. - Lotek Wireless, Ontario.

[43] Lotek Wireless (2004): Product sheet: GPS_2200 collar for livestock. <www.lotek.com/gps_22001.pdf> [Last accessed April 2007].

[44] MacDonald, A., Stevens, P., Armstrong, H., Immirzi, P., Reynolds, P. (1998): A Guide to Upland Habitats: Surveying Land Management Impacts. Volume 1, Background Information and Guidance for Surveyors. - Scottish Natural Heritage, Perth.

[45] McNaughton, S.J. (1984): Grazing lawns: animals in herds, plant form, and coevolution. - American Naturalist 124: 863-886.

[46] Met Éireann (undated): Climate of Ireland. <www.met.ie/climate/climate-of-ireland.asp> [Last accessed April 2007].

[47] Milligan, A.L., Putwain, P.D., Cox, E.S., Ghorbani, J., Le Duc, M.G., Marrs, R.H. (2004): Developing an integrated land management strategy for the restoration of moorland vegetation on Molinia caerulea-dominated vegetation for conservation purposes in upland Britain. - Biological Conservation 119: 371-385.

[48] Moravec, J., Zemeckis, R. (2007): Cross Compliance and Land Abandonment. Institute for European Environmental Policy, Brussels.

[49] National Parks and Wildlife Service (2005): Farm Plan Scheme for Designated Areas and Commonages: Specifications Document. - The National Parks and Wildlife Service, Dublin. 
[50] National Parks and Wildlife Service (2008): The Status of EU Protected Habitats and Species in Ireland. Report available online:

<www.npws.ie/en/PublicationsLiterature/HabitatsDirectivereport07>.

[51] O'Dowd, D. (2005): A study of the vegetation of sheep rests at Teagasc Hill Sheep farm, Leenaun, with particular reference to Nardus stricta. - Unpublished BSc Thesis, National University of Ireland, Galway.

[52] O'Toole, M.A. (1985): History, distribution and stocking intensities of hill sheep in Ireland. - Journal of Life Sciences Royal Dublin Society 5: 87-92.

[53] Pearce-Higgins, J.W., Grant, M.C. (2006): Relationships between bird abundance and the composition and structure of moorland vegetation. - Bird Study 53: 112-125.

[54] Rawes, M. (1983): Changes in two high altitude blanket bogs after the cessation of sheep grazing. - Journal of Ecology 71: 219-235.

[55] Rowell, T.A., Clarke, M.J. (1988): Grazing. - In: Rowell, T.A. (ed.) The Peatland Management Handbook: Research and Survey in Nature Conservation No. 14, Nature Conservancy Council, Peterborough.

[56] Thompson, D.B.A., MacDonald, A.J., Marsden, J.H., Galbraith, C.A. (1995): Upland heather moorland in Great Britain: a review of international importance, vegetation change and some objectives for nature conservation. - Biological Conservation 71: 163178.

[57] van Eck, H., Govers, A., Lemaire, A., Schaminée (1984): Irish Bogs: a Case for Planning. - Katholieke Universiteit, Nijmegen.

[58] Walsh, M., Mulqueen, J., Grennan, E., Rogers, M., Marren, N., Guinan, L., Nixon, D., Collins, J.F. (2000): Evaluation of the Impact of Livestock on the Hill Environment. End of Project Reports: Sheep Series No. 10. Project No. 4043. Teagasc Agriculture and Food Development Authority, Sheep Research Centre, Athenry.

[59] Warren, J.T., Mysterud, I. (1991): Summer habitat use and activity patterns of domestic sheep on coniferous forest range in southern Norway. - Journal of Range Management 44: 2-6.

[60] Welch, D. (1984): Studies in the grazing of heather moorland in north-east Scotland. I. Site descriptions and patterns of utilization. - Journal of Applied Ecology 21: 179-195.

[61] Williams, B. (2008): Resource selection by Scottish Blackface sheep on a mosaic of upland and peatland habitats: implications for conservation management. - Unpublished $\mathrm{PhD}$ thesis, National University of Ireland, Galway. 